\begin{tabular}{|c|c|c|}
\hline ENGINEERING CHANGE NOTICE & Page 1 of $\frac{14}{32}$ & ${ }_{\substack{\text { Prol. } \\
\text { ECN }}}$ ECN $\mathrm{NO} 624505$ \\
\hline
\end{tabular}

\begin{tabular}{|c|c|c|c|c|}
\hline \multirow{3}{*}{$\begin{array}{l}\text { 2. ECN Category } \\
\text { (mark one) } \\
\text { Supplemental } \\
\text { Direct Revision } \\
\text { Change ECN } \\
\text { Temporary } \\
\text { Standby } \\
\text { Supersedure } \\
\text { Cancel/Void }\end{array}$} & \multirow{3}{*}{$\begin{array}{l}{[]} \\
{[\mathrm{X}]} \\
] \\
{[} \\
0 \\
0 \\
{[]} \\
{[]}\end{array}$} & $\begin{array}{l}\text { 3. Originator's Name, Organization, MSIN, and } \\
\text { Telephone No. } \\
\text { R.W. Lysher, S0-08, 376-0979 }\end{array}$ & 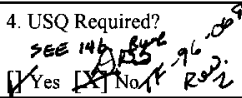 & $\begin{array}{l}\text { 5. Date } \\
\text { November } 10,1998\end{array}$ \\
\hline & & $\begin{array}{l}\text { 6. Project Title/No/Work Order No. } \\
\text { DST Ultrasonic Inspection/L9F014 }\end{array}$ & $\begin{array}{l}\text { 7. Bldg./Sys./Fac. No. } \\
200 \text { E/Tank Farms }\end{array}$ & Difyrigual Designator \\
\hline & & $\begin{array}{l}\text { 9. Document Numbers Changed by this ECN } \\
\text { (includes sheet no. and rev.) } \\
\text { HNF-2820 REV } 0 .\end{array}$ & 10. Related ECN No(s). & 11. Related PO No. \\
\hline
\end{tabular}

\begin{tabular}{|c|c|c|c|}
\hline 12a. Modification Work & $\begin{array}{l}\text { 12b. Work Package } \\
\text { No. }\end{array}$ & 12c. Modification Work Complete & $\begin{array}{l}\text { 12d. Restored to Original Condition (Temp. } \\
\text { or Standby ECN only) }\end{array}$ \\
\hline [] Yes (fill out Blk. 12b) & $\mathrm{N} / \mathrm{A}$ & N/A & $N / A$ \\
\hline $\begin{array}{c}{[\mathrm{X}] \text { No (NA Blks. 12b, }} \\
12 \mathrm{c}, 12 \mathrm{~d})\end{array}$ & & $\begin{array}{l}\text { Design Authority/Cog. Engineer } \\
\text { Signature \& Date }\end{array}$ & $\begin{array}{l}\text { Design Authority/Cog. Engineer } \\
\text { Signature \& Date }\end{array}$ \\
\hline
\end{tabular}

13a. Description of Change

13b. Design Baseline Document? [] Yes [X] No

THIS IS A DIRECT REVISION TO ENGINEERING TASK PLAN (ETP) HNF-2820, REV. 0 "ENGINEERING TASK PLAN FOR THE ULTRASONIC INSPECTION OF HANFORD DOUBLE-SHELL TANKS".

\begin{tabular}{|c|c|c|c|c|c|c|c|}
\hline \multicolumn{8}{|c|}{ 14a. Justification (mark one) } \\
\hline Criteria Change & {$[\mathrm{x}]$} & Design Improvement & [] & Environmental & & Facility Deactivation & [] \\
\hline As-Found & {[]} & Facilitate Const & & Const. Error/Omission & {$[7$} & Design Error/Omission & [] \\
\hline
\end{tabular}

14b. Justification Details

- $\quad$ ADDITIONAL TANKS ARE IDENTIFIED FOR INSPECTION PERSUANT TO DOCUMENT HNF-2820, REV 0. "ENGINEERING TASK BQAA FOR THE ULTRASONIC INSPECTION OF HANFORD DOUBLE-SHELL TANKS".

- NOUSQTS REQUIRED FOR THIS ECN AS DEFINED IN HNF-IP-0842 REV 10H, "UNREVIEWED SAFETY QUESTIONS", CATIGORICAL EXCLUSION.

\begin{tabular}{|lllllll}
\hline 15. Distribution (include name. MSIN, and no. of copies) & & \\
DC Pfluger & R1-56 & 1 COPY & DB Baide & S5-05 & 1 COPY \\
DB Smet & R1-56 & 1 COPY & DL Sparks & S5-03 & 1 COPY \\
RW Lysher & S0-08 & 1 COPY & PG O'Conner & S5-04 & 1 COPY \\
RS Nicholson & S5-05 & 1 COPY & GR Tardiff & S5-05 & 1 COPY \\
CE Jensen & R1-56 & 1 COPY & KV Scott & S7-12 & 1 COPY \\
EA Nelson & L6-38 & 1 COPY & & &
\end{tabular}




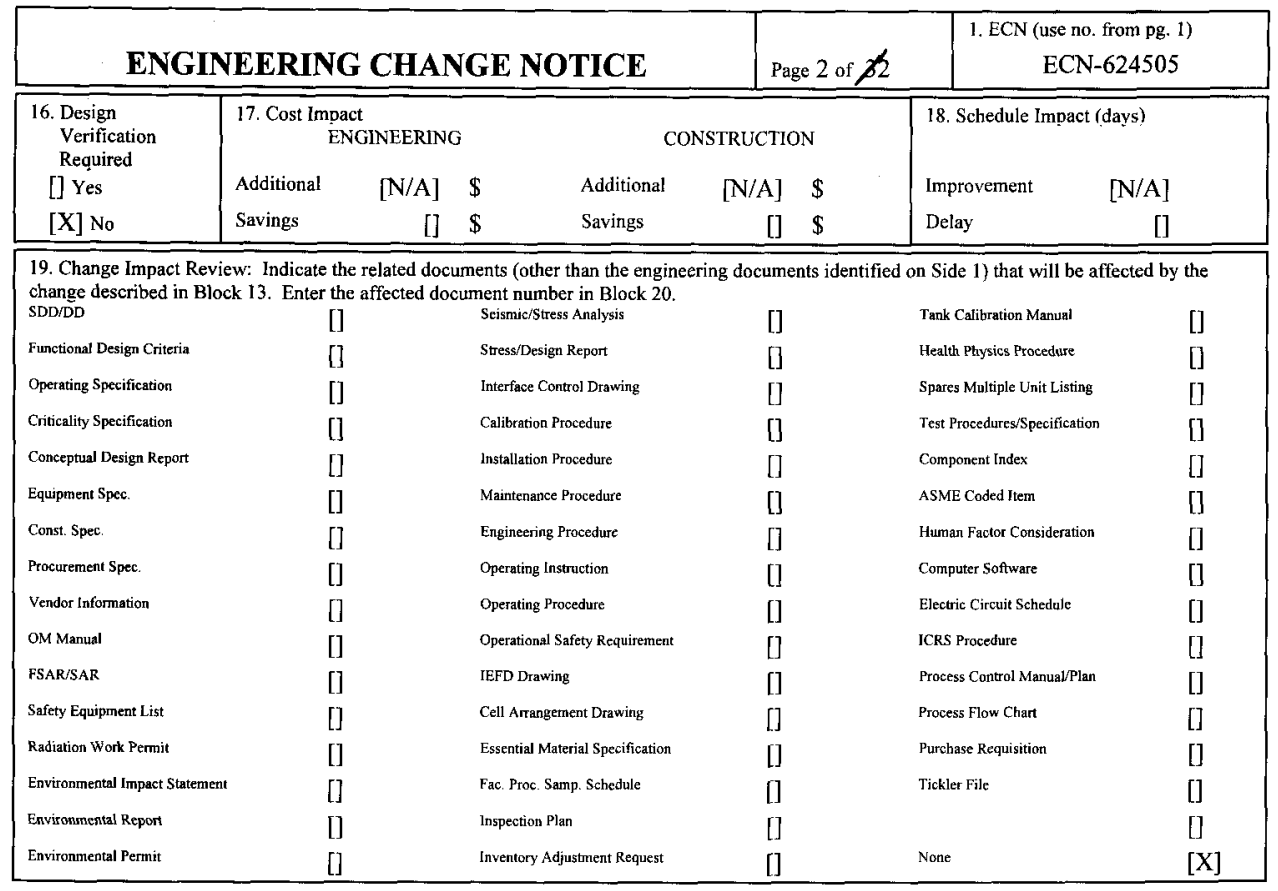

20. Other Affected Documents: (NOTE: Documents listed below will not be revised by this ECN.) Signatures below indicate that the signing organization has been notified of other affected documents listed below.

Document Number/Revision Document Number/Revision

Document Number Revision
N/A
N/A
N/A

21. Approvals

LMHC Proj, Eng. CE Jensen

LHMC Proj. Eng. DC Pfluger

LHMC Proj. Mng. DB Smet

AN-AW Cog. Eng. RS Nicholson

AZ-AY Cog. Eng. GR Tardiff

DST Eng. Cog. Mgr. DB Baide

Opr. Mng. DL Sparks

Cogema Proj. Mng. KV Scott

UT Proj. Mng. EA Nelson

Prod. Cntrl. Mng. RS Rodriquez

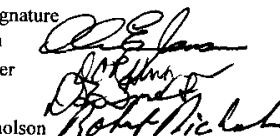

$1210 \% 8$

98

$12 / 7 / 98$

12) 98 PE

$\frac{4-8.95}{12110198}$

Pespougo"

1710149

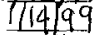

-0.82 ran

>lukeft

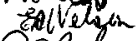

$1 / 18 / 99$

L2-3.98

$1+19 \cdot 29$

$12-8-28$

Lead/Field Eng. RW Lysher

Informal Rev. GA Leshikar

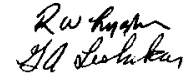

$1 D E \angle 98$

$12 / 3 / 98$

Design Agent

PE

QA

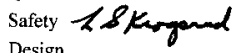

Design

Environ.

Other

DEPARTMENT OF ENERGY

Signature or a Control Number that tracks the

Approval Signature

ADDITIONAL 


\title{
Engineering Task Plan for the Ultrasonic Inspection of Hanford Double-Shell Tanks
}

\author{
RW Iysher \\ Cogema Engineering Corporation \\ Richland, WA 99352 \\ U.S. Department of Energy Contract DE-AC06-96RL13200 \\ $\begin{array}{lll}\text { EDT/ECN: } & \text { ECN } 624505 & \text { UC: } \\ \text { Org Code: } & 08 \mathrm{E} 00 & \text { Charge Code: L9F014 } \\ \text { B\&R Code: } & \text { Ew3120071 } & \text { Total Pages: } 32\end{array}$
}

Key Words: ultrasonic, UT, NDE, non-destructive examination, examination, inspection

\begin{abstract}
This document facilitates the ultrasonic examination of Hanford Double-Shell Tanks. Included are a plan for engineering activities (individual responsibilities), plan for performance demonstration testing, and a plan for field activities (tank inspection). Also included are a statement of work (SOW) for contractor performance of the work and a protocol to be followed should tank flaws that exceed the acceptances criteria be discovered.
\end{abstract}

TRADEMARK DISCLAIMER. Reference herein to any specific commercial product, process, or service by trade name, trademark, manufacturer, or otherwise, does not necessarily constitute or imply its endorsement, recommendation, or favoring by the United States Government or any agency thereof or its contractors or subcontractors.

Printed in the United States of America. To obtain copies of this document, contact: Document Control Services, P.O. Box 950, Mailstop H6-08, Richland WA 99352, Phone (509) 372-2420; Fax (509) 376-4989.

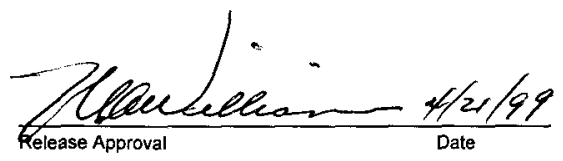

Approved For Public Release

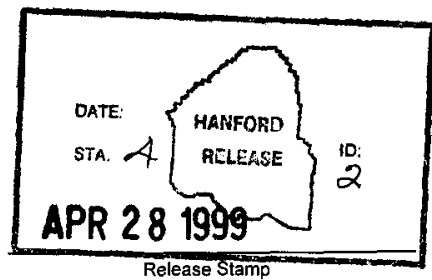

Release Stamp 


\section{RECORD OF REVISION}

(2) Titte

Engineering Task Plan for the Ultrasonic Inspection of Hanford Double-Shell Tanks

Change Control Record

(3) Revision

1 RS
Authorized for Release

(4) Description of Change - Replace, Add, and Delete Pages

Complete replacement of document

\begin{tabular}{l|l} 
(5) Cog. Engr. & (6) Cog. Mgr
\end{tabular}

Date

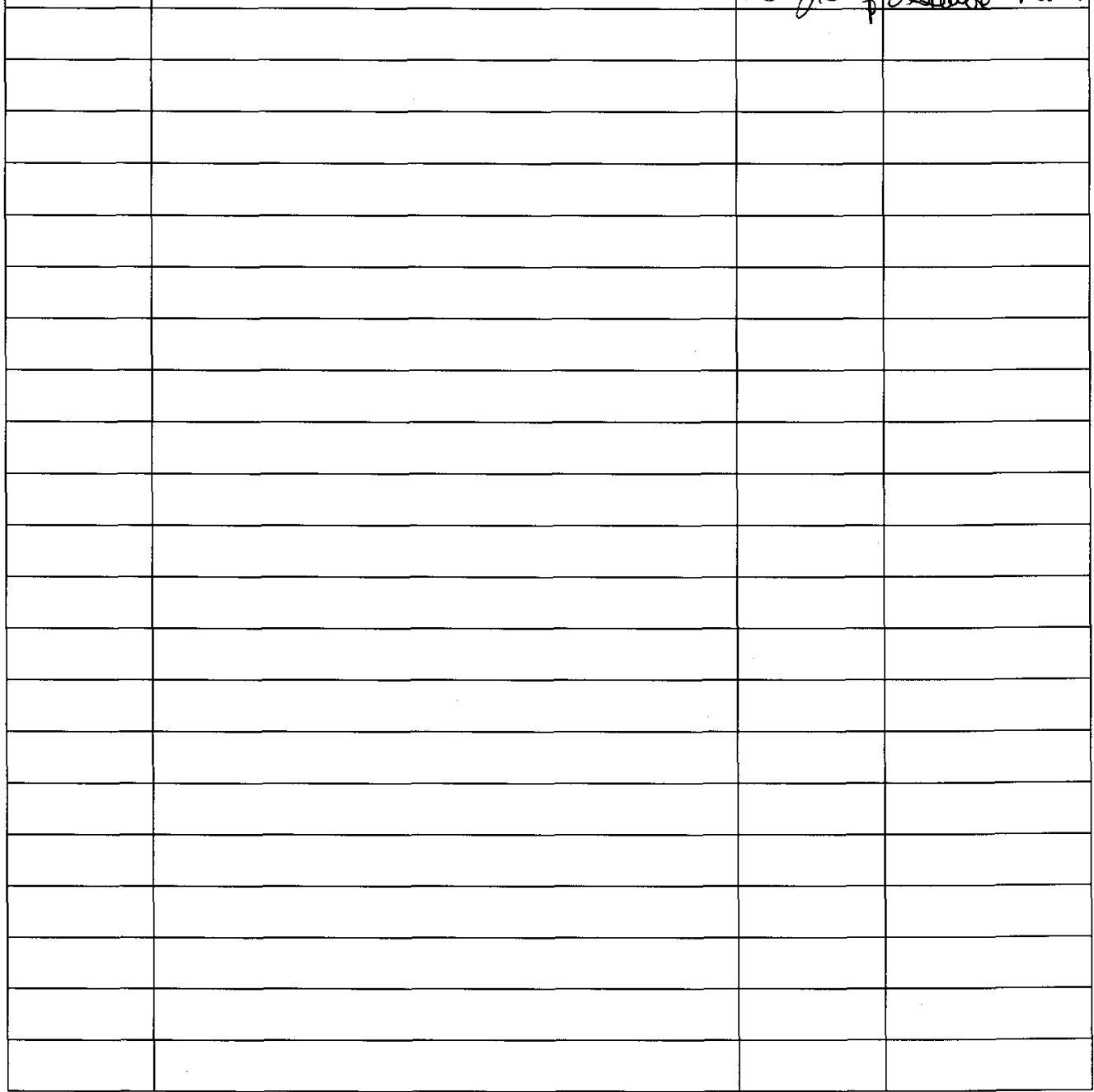




\section{Contents}

1. Introduction

2. Objective and Scope

3. Equipment Description

4. Plan For Engineering Activities

5. Plan For Performance Demonstration Testing

6. Plan For Field Activities (Tank Inspection)

7. Cost and Schedule

8. Mechanism for Equipment Turnover

9. Records

10. References

APPENDIX A, INSPECTION REVIEW PANEL CHARTER

APPENDIX B, TANKS IDENTIFIED FOR INSPECTION WITH INSPECTION DURATIONS

APPENDIX C, STATEMENT OF WORK (SOW)

TABLE 1, TANK AIR SLOT ARRANGEMENT

FIGURE 1, TYPICAL TANK ELEVATION VIEW 


\section{Engineering Task Plan for the Ultrasonic Inspection of Hanford Double-Shell Tanks}

\subsection{Introduction}

In May 1996, the TWRS Decision Board recommended and RL agreed that the condition of the double-shell tanks (DSTs) should be determined by ultrasonic (UT) inspection of a limited area in six of the 28 DSTs. The Washington State Department of Ecology (WDOE) has agreed with the strategy of limited ultrasonic inspection of six DSTs. Data collected during the UT inspections will be used to assess the condition of the tank, judge the effects of past corrosion control practices, and satisfy a regulatory requirement to periodically assess the integrity of waste tanks.

In November, 1996, DST 241-AW-103 was inspected to determine if Hanford DST walls could be inspected without removing the existing surface rust and scale. Equipment similar to that used to perform routine inspections of oil tanks and large pipelines was used. Ultrasonic sensors were mounted on a remote-controlled crawler that used magnetic wheels to affix itself and move about on the tank walls. The crawler was deployed into the tank annulus and vertically traversed the primary and secondary containment walls to collect data on the wall thickness and the size of any pits or cracks. The successful completion of this inspection met the requirements of RL milestone T21-97-455 and represented the first ultrasonic inspection of a Hanford DST (Leshikar 1997).

Based on the results of the initial inspection, a Statement Of Work (SOW) was prepared for the remaining DST inspections scheduled for fiscal year 1998 and beyond. The next DST to be inspected was 241-AN-107. The inspection was completed in September 1998 and is the subject of FY 98 Performance Agreement TWR 1.2.13. The final five DST's have been prioritized for inspection based on the selection criteria given in (Schwenk and Scott 1996) and (Anantatmula 1997). Four of the tanks are the subject of the FY 99 Performance Agreement (PA) TWR 6.3.1.

\subsection{Objective and Scope}

The objective of this engineering task plan (ETP) is to ultrasonically examine the walls, lower knuckle, and bottom of DSTs using equipment provided and operated by a UT inspection vendor. This ETP is an overall plan for task completion that details the roles and responsibilities of individuals involved in the examination process. Included herein is the Statement of Work, the plan for engineering activities, the plan for performance demonstration testing of the examination equipment, and the plan for conducting field activities (tank inspection). Also included is the protocol to be followed should tank flaws that exceed the acceptance criteria be discovered. 


\subsection{Objective and Scope Cont'd}

This ETP facilitates the UT examinations of DSTs as described in WHC-SD-WM-AP-017, Rev. 1, "Tank System Integrity Assessments Program Plan," (Pfluger 1994) which was submitted to WDOE meeting a Tri-Party Agreement milestone in June, 1998. This ETP was written in compliance with HNF-PRO-283, Rev. 2, "Control of Inspections" (Byers 1998).

\subsection{Equipment Description}

Generally, a UT examination will include a remote-controlled delivery vehicle (i.e. scanner or crawler) carrying ultrasonic sensors that glide over the surface to be inspected. A liquid media physically couples the sensors to the surface. Data and images are returned to a manned control center that contains the scanner controls, video monitors, and data collection and evaluation hardware. Remotely operated cameras observe the operation. Lighting of the DST annular space and inspection area is required.

Different types of vehicles for delivering the ultrasonic sensors to the tank areas of interest may be required, dependent on the scope of the particular DST examination. Each shall be qualified by performance demonstration testing. A device or devices for inserting and removing the equipment from the DST riser is generally needed.

\subsection{Plan for Engineering Activities}

The table on the following pages identifies the engineering tasks, by responsible individual, that need to be performed in order to complete an inspection. Nothing in this ETP prevents a person from assuming more than one role for an inspection (such as the field engineer and lead engineer being the same person), or two persons dividing up the responsibilities of one role. 


\begin{tabular}{|c|c|}
\hline $\begin{array}{l}\text { RESPONSIBLE } \\
\text { INDIVIDUAL }\end{array}$ & ENGINEERING TASKS \\
\hline $\begin{array}{l}\text { Inspection Cognizant } \\
\text { Engineer }\end{array}$ & $\begin{array}{l}\text { 1. Select tank for inspection. } \\
\text { 2. Determine scope of inspection (walls, knuckle, welds, and/or tank } \\
\text { bottom) } \\
\text { 3. Approve inspection detection (sizing) criteria, included in SOW. } \\
\text { 4. Select UT Inspection Contractor per SOW. } \\
\text { 5. Develop schedule for task completion. } \\
\text { 6. Approve UT inspection system for use in tank based on } \\
\text { recommendation of UT Technical Expert and Lead Engineer. } \\
\text { 7. Approve equipment deployment/ retrieval procedures } \\
\text { 8. Lead Inspection Review Panel, should flaws be discovered } \\
\text { 9. Review/approve Tank Inspection Report } \\
\text { 10. Technical cognizance over examination data / Data Management } \\
\text { Plan }\end{array}$ \\
\hline $\begin{array}{l}\text { Facility Cognizant } \\
\text { Engineer }\end{array}$ & $\begin{array}{l}\text { 1. Review/approve equipment deployment/ retrieval procedures } \\
\text { 2. Approve work packages }\end{array}$ \\
\hline Facility Manager & $\begin{array}{l}\text { 1. Approve scope of activities } \\
\text { 2. Provide personnel to support scope of work (PIC, planners, camera } \\
\text { crew, operators, HPT's, etc.) }\end{array}$ \\
\hline Planner & $\begin{array}{l}\text { 1. Develop work package } \\
\text { 2. Help resolve tank farm interface issues (radiological, permits, safety, } \\
\text { etc.) }\end{array}$ \\
\hline Field Engineer & $\begin{array}{l}\text { 1. Prepare engineering documentation supporting field activities (ETP's, } \\
\text { test plans, USQ's, status, etc) } \\
\text { 2. Engineering interface between the inspection contractor and the tank } \\
\text { farm facility } \\
\text { 3. Coordinate inspection contractor utility needs (control center siting, } \\
\text { power, water, etc.) with facility restrictions } \\
\text { 4. Design and arrange fabrication of special support equipment as } \\
\text { required (temporary riser caps, weather protection, etc.) } \\
\text { 5. Track work package development } \\
\text { 6. Arrange contractor training } \\
\text { 7. Provide support during tank inspection } \\
\text { 8. Prepare Tank Inspection Report for approval by all parties. }\end{array}$ \\
\hline
\end{tabular}




\begin{tabular}{|l|l|}
\hline Lead Engineer & $\begin{array}{l}\text { 1. Overall activity leader } \\
\text { 2. Lead status meetings between engineering and facility personnel. } \\
\text { 3. Technical interface with the UT Inspection Contractor } \\
\text { 4. Coordinate and lead performance demonstration tests. } \\
\text { 5. Approve UT equipment navigational capabilities and deployment } \\
\text { capability from tank riser per performance demonstration tests. }\end{array}$ \\
& $\begin{array}{l}\text { 6. Review UT equipment deployment/retrieval procedures } \\
\text { 7. Ensure work is performed in accordance with this ETP. }\end{array}$ \\
\hline UT Inspection Technical & $\begin{array}{l}\text { 1. Verify examination personnel qualifications } \\
\text { 2. Approve calibration procedures, examination procedures, and } \\
\text { standards documentation }\end{array}$ \\
$\begin{array}{ll}\text { 3. Witness UT system performance demonstration test } \\
\text { 4. Approve UT system per code and SOW criteria. } \\
\text { 5. Provide report documenting UT system qualification. } \\
\text { 6. Review tank inspection data }\end{array}$ \\
$\begin{array}{l}\text { 7. Provide input to and approve Tank Inspection Report } \\
\text { UT Inspection }\end{array}$ & $\begin{array}{l}\text { See SOW (Appendix C) for more detail. } \\
\text { - Provide ultrasonic inspection equipment } \\
\text { - Provide a facility/mock-up for performance demonstration testing } \\
\text { - Test \& operate equipment in tank mock-up } \\
\text { - Set-up \& operate equipment in waste tank } \\
\text { - Interpret \& deliver inspection data }\end{array}$ \\
\hline \hline
\end{tabular}

\subsection{Plan for Performance Demonstration Testing}

Prior to inspection of a DST, the UT inspection contractor shall demonstrate the ability of their measurement system to detect and size flaws, and to remotely navigate areas to be examined via a mock-up(s) as described in the SOW.

The performance demonstration test (PDT) is designed to qualify the personnel, procedure, and equipment that will be used to inspect the DST. The requirements for the PDT follow practices outlined in Section XI, Appendix VIII of the ASME Code. Requirements established in SNTTC-1A-92 will be followed to assess personnel qualifications. ASME Section V outlines the general requirements for inspection procedures; however, a specific procedure is to be prepared by the UT inspection contractor that addresses how the inspection of the DST is to be performed.

The qualification of the UT system to be used will be based on the successful examination of a series of test plates that are to be supplied by LMHC. The test plates contain stress corrosion cracks, simulated pitting, and wall thinning. Detection (sizing) criteria are provided in the SOW. System acceptance criteria are based on the statistical procedure described in Section XI, Appendix VIII of the ASME Code. Once qualified, the system is considered qualified for as long as the personnel, procedure, and equipment remain unchanged. 


\subsection{Plan for Performance Demonstration Testing Cont'd}

Per the SOW the UT inspection contractor shall provide a partial mockup(s) of a DST. The UT inspection contractor shall demonstrate the insertion and retrieval of their measurement equipment into/from the mock-up riser. In addition, the following items are to be evaluated subject to the scope of the DST examination:

- Ability of equipment to navigate obstacles and obstructions in the mock-up annulus

- Ability of equipment to examine welds and plate areas

- Ability of equipment to navigate mock-up primary and secondary tank knuckles

- Ability of equipment to navigate inside mock-up channels simulating tank bottom air slots.

The UT Inspection Technical Expert shall produce a report documenting the results of the UT system qualification. The Lead Engineer shall make a recommendation in the PDT report as to whether navigation capabilities have been adequately demonstrated. Final approval of the UT system for use in a Hanford waste tank is the responsibility of the Inspection Cognizant Engineer.

\subsection{Plan for Field Activities (Tank Inspection)}

Individual work packages will be prepared for each DST UT examination. Work packages will be the vehicle for performance of the UT examination. All work steps, guidelines, procedures, and charters, (including the contractors) will be included or referenced in the work package. The examination will proceed according to the work instructions in the approved work package. The work instructions will point to the applicable guideline, procedure, or charter as needed.

The Facility Manager will designate an Operations Person-In-Charge (PIC) who has overall authority over the field performance of the inspection. This person will work closely with the Lead Engineer to ensure that work proceeds per the work instructions. Discovery of a flaw in a tank above the limits specified in the acceptance criteria will be documented using the process for resolution as stated in Appendix A. The inspection is expected to continue after discovery of a flaw. Unless a problem is an emergency or immediate safety concern, the PIC is required to obtain input from the Lead Engineer and Contractor Lead before rendering decisions.

The specific items listed below cover the bulk of the field activities. The responsible individual listed under each item has authority and responsibility for that aspect of the inspection work.

- Work to be performed by Tank Farms personnel (removal of annulus shield plug, preparation around riser, HPT survey of equipment, etc.) will have designated steps in the work package.

Responsible Individual: PIC (person in charge)

- Set-up and operation of an overview camera and lights inserted in an adjacent riser to the 24 " inspection riser. Communications between the Tank Farms camera operator, UT control center, and personnel at the inspection riser will be established.

Responsible Individual: PIC 


\subsection{Plan for Field Activities (Tank Inspection) Cont'd}

- A functional test of the contractor's examination equipment shall be performed at the tank farm before the equipment is deployed. This will be documented, at minimum, by a sign-off within the work package.

Responsible Individual: Contractor Lead

- Deployment and retrieval of the examination equipment from the annulus is the responsibility of the contractor, and will be performed by the contractor. The contractor will provide a plan or procedure for deployment and retrieval. However, for safety and ALARA reasons it is realized that the PIC will need to be present and have authority in case unanticipated problems are encountered.

Responsible Individual: PIC

- Set-up and functional checks of the contractor's examination equipment and control center, performance of the UT examination, and data collection are the responsibility of the contractor. The contractor will provide UT examination procedures that comply with the ASME code and at inspection completion provide the complete set of data collected to the Lead Engineer.

Responsible Individual: Contractor Lead

- A contractor individual certified to SNT-TC-1A-92 will review the inspection data as it is being obtained for any indication of flaws in excess of the acceptance criteria. This individual is the final interpreter of flaw magnitude. The SOW includes the acceptance criteria for the inspection. The acceptance criteria was developed using WHC-SD-WM-AP036, "Acceptance Criteria for Non-Destructive Examination of Double-Shell Tanks", Rev. 0 (Jensen 1995).

Responsible Individual: Contractor Lead

- If the SNT-TC-1A-92 certified inspector discovers a flaw or flaws that exceeds the established acceptance criteria, the Lead Engineer, and Inspection Cognizant Engineer shall be immediately notified. The Cognizant Engineer shall convene an Inspection Review Panel, which will make recommendations within 24 hours of the flaw(s) discovery. The Responsible Individual will provide a charter (see Appendix A) detailing the panel make-up, expertise, and protocol. The panel will make recommendations to the facility manager based on the severity and number of flaws found.

Responsible Individual: Inspection Cognizant Engineer

- Recommendations and findings of the Inspection Review Panel will be processed according to the occurrence reporting procedures.

Responsible Individual: Facility Manager 


\subsection{Cost and Schedule}

See Appendix B for FY99 tank inspection schedules.

\subsection{Mechanism for Equipment Turnover}

Until UT inspections from the annuli of DST are considered routine, there will be no equipment turnover or Acceptance for Beneficial Use (ABU). At a future date when inspections become routine, an $\mathrm{ABU}$ will be issued.

Note: The UT Inspection Contractor provides the equipment for the inspection, all equipment brought by the contractor is to be removed after the inspection is performed, and there are no permanent facility modifications.

\subsection{Records}

The following records will be prepared as a result of this work:

- Plan for Deployment and Retrieval of UT Equipment from a Double Shell Tank (Contractor)

- Ultrasonic Examination Procedures (Contractor)

- Performance Demonstration Test Report (UT Technical Expert and Lead Engineer)

- Unreviewed Safety Question screening or determination (Lead Engineer)

- NDE Report (Contractor)

- Final report that presents and explains data from DST examination (Lead Engineer and UT Technical Expert)

The final report will be a supporting document, approved and released in accordance with HNF-PRO-439, Rev. 0, "Project Hanford Policy and Procedure System - Supporting Document Requirements," (Skriba 1997). The final report will also include copies of the above listed records. 


\subsection{References}

Anantatmula, R.P., 1997, Prioritization of Double-Shell Tanks for Ultrasonic Examination, (internal letter 74700-97-RPA-009 to K.V. Scott, March 17), Lockheed Martin Hanford Corporation, Richland, Washington.

Byers, S.A., 1998, Control of Inspections, HNF-PRO-283, Rev. 2, Fluor Daniel Hanford Company, Richland, Washington.

Ellis, S.H., 1997, TWRS Administration, WHC-IP-0842, Rev. 0, Westinghouse Hanford Company, Richland, Washington.

Jensen, C.E., 1995, Acceptance Criteria for Non-Destructive Examination of Double-Shell Tanks, WHC-SD-WM-AP-036, Rev. 0, Westinghouse Hanford Company, Richland, Washington.

Leshikar, G.A., 1997, Final Report - Ultrasonic Examination of Tank 24l-AW-103 Walls, HNFSD-WM-TRP-282, Rev. 0, SGN Eurisys Services Corporation, Richland, Washington.

Pfluger, D.C., 1994, Tank System Integrity Assessments Program Plan, WHC-SD-WM-AP-017, Rev. 1, Westinghouse Hanford Company, Richland, Washington.

Schwenk, E.B., and Scott, K.V., 1996, Description of Double-Shell Tank Selection Criteria for Inspection, WHC-SD-WM-ER-529, Rev. 1, Westinghouse Hanford Company, Richland, Washington.

Skriba, M.C., 1997, Project Hanford Policy and Procedure System - Supporting Document Requirements, HNF-PRO-439, Rev. 0, Fluor Daniel Hanford Corporation, Richland, Washington.

Leshikar, G.A., 1998, Results Of Tank 241-AN-107 Ultrasonic Examination", HNF-3353 Rev 0, Lockheed Martin Hanford Corporation, Richland, Washington. 
HNF-2820

APPENDIX A

REV. 1

APPENDIX A

INSPECTION REVIEW PANEL CHARTER 
HNF-2820

APPENDIX A

REV. 1

\section{Inspection Review Panel Charter}

The panel is charged with making technical recommendations to the tank facility manager within 24-hours following discovery of flaws that exceed the established acceptance criteria ${ }^{1}$. The panel's recommendations will focus on any immediate actions needed to maintain adequate waste confinement and on any immediate actions needed to gather more data on the discovered flaw. At a later time, the panel will review all the ultrasonic inspection data collected for each tank and prepare a summary report with recommendations for future inspections.

The panel will consist of individuals with experience and technical expertise in ultrasonic data interpretation, fracture analysis, structural analysis, corrosion, and the tank safety basis. One member of the panel will be the Design Authority for the tank. An individual with an overall understanding of the inspection process and the role of the panel will administer the panel. The panel recommendations will be submitted to the tank facility manager and made available to others on request. The tank facility manager will determine if the discovered flaws are to be reported as an occurrence. Occurrence reporting is described in HNF-IP-0842, Volume II, Section 4.6.2, "Occurrence Reporting and Processing of Operations Information".

The panel recommendations will be based on the severity and number of flaws found. The panel will judge the severity of the flaw from the flaw size, flaw location, fracture potential, growth potential, tank failure consequences, and planned use of the tank. The recommendations could include re-examination of the same flaw, additional examination of the same tank, examination of other tanks, removing a tank from service, lowering the tank waste level, repairs, periodic monitoring for flaw growth, adjusting the tank chemistry, or no action. Westinghouse Hanford Company report WHC-SD-WM-AP-036, Rev. 0, "Acceptance Criteria for Non-Destructive Examination of Double-Shell Tanks" (Jensen 1995), and its references are available to assist the panel in their evaluation of flaws. Westinghouse Hanford Company report WHC-SD-WM-ER529, Rev. 1, "Description of Double-Shell Tank Selection Criteria for Inspection" (Schwenk and Scott 1996), and its references are available to assist the panel in determining how representative the inspection results are in relation with other tanks and what additional tanks should be considered for inspection. 
HNF-2820

APPENDIX A

REV. 1

\section{References}

TWRS Administration, HNF-IP-0842, Fluor Daniel Hanford Company, Richland, Washington.

Jensen, C.E., 1995, Acceptance Criteria for Non-Destructive Examination of Double-Shell Tanks, WHC-SD-WM-AP-036, Rev. 0, Westinghouse Hanford Company, Richland, Washington.

Schwenk, E.B., and Scott, K.V., 1996, Description of Double-Shell Tank Selection Criteria for Inspection, WHC-SD-WM-ER-529, Rev. 1, Westinghouse Hanford Company, Richland, Washington. 
HNF-2820

APPENDIX B

REV. 1

APPENDIX B

TANKS IDENTIFIED FOR INSPECTION WITH INSPECTION DURATIONS 


\section{DST Inspection: Tank 241-AN-107}

The first DST selected for UT examination under this ETP was Tank 241-AN-107. The walls, lower knuckle, and the bottom of the tank (via the air slots) were examined. This inspection satisfied the FY 98 Performance Agreement TWR 1.2.13. Information on this inspection can be found in document HNF-3353 Rev 0. "Results Of Tank 241-AN-107 Ultrasonic Examination", (Leshikar 1998).

An inspection program to complete five more DST tanks was initiated in October 1998. This inspection will satisfy the FY 99 Performance Agreement (PA) TWR 6.3.1. Completion of this PA is scheduled for July 15, 1999. The cost and schedule of the project is addressed in Contract Number 521, Release \#14. Due to variables such as field conditions, facility status, and other DST programs, the order of tanks to be inspected is tentative. As conditions change the facility order may also change. The following is a list of the tanks to be inspected with performing tasks and duration's:

\section{DST Inspection: Tank 241-AN-105,}

The second DST selected for UT examination is Tank 241-AN-105. The walls, lower knuckle, and the bottom of the tank (via the air slots) are to be examined

\begin{tabular}{|l|l|}
\hline Task & Duration \\
\hline Work Package/ Inspection Equipment Preparation & 1 Week \\
\hline Equipment setup at AN tank farm, functional checks & 1 Week \\
\hline Perform inspection of wall, knuckle, floor and bottom of Tank 241-AN-105 & 6 Weeks \\
\hline Prepare and issue tank examination report & 3 Weeks \\
\hline
\end{tabular}

\section{DST Inspection: Tank 241-AY-102,}

The third DST selected for UT examination is Tank 241-AY-102. The walls, weids, lower knuckle, and the bottom of the tank (via the air slots) are to be examined.

\begin{tabular}{|l|l|}
\hline Task & Duration \\
\hline Work Package Preparation & 1 Week \\
\hline Equipment setup at AY tank farm, functional checks & 1 Week \\
\hline Perform inspection of wall, knuckle, and bottom of Tank 241-AY-102 & 4 Weeks \\
\hline Prepare and issue tank examination report & 3 Weeks \\
\hline
\end{tabular}


HNF-2820

APPENDIX B

REV. 1

\section{DST Inspection: Tank 241-AZ-101,}

The fourth DST selected for UT examination is Tank 241-AZ-101. The walls, lower knuckle, and the bottom of the tank (via the air slots) are to be examined.

\begin{tabular}{|l|l|}
\hline Task & Duration \\
\hline Work Package Preparation & 1 Week \\
\hline Equipment setup at AZ tank farm, functional checks & 1 Week \\
\hline $\begin{array}{l}\text { Perform inspection of primary wall only, primary and secondary knuckles, } \\
\text { and primary and secondary bottoms of Tank 241-AZ-101 }\end{array}$ & 7 Weeks \\
\hline Prepare and issue tank examination report & 3 Weeks \\
\hline
\end{tabular}

\section{DST Inspection: Tank 241-AY-101,}

The fifth DST selected for UT examination is Tank 241-AY-101. The walls, welds, lower knuckle, and the bottom of the tank (via the air slots) are to be examined.

\begin{tabular}{|l|l|}
\hline Task & Duration \\
\hline Work Package Preparation & 1 Week \\
\hline Equipment setup at AY tank farm, functional checks & 1 Week \\
\hline Perform inspection of wall, knuckle, and bottom of Tank 241-AY-101 & 4 Weeks \\
\hline Prepare and issue tank examination report & 3 Weeks \\
\hline
\end{tabular}

\section{DST Inspection: Tank 241-AW-103,}

The sixth DST selected for UT examination is Tank 241-AW-103. The wall welds, and the bottom of the tank (via the air slots) are to be examined.

\begin{tabular}{|l|l|}
\hline Task & Duration \\
\hline Work Package Preparation & 1 Week \\
\hline Equipment setup at AW tank farm, functional checks & 1 Week \\
\hline $\begin{array}{l}\text { Perform inspection of wall welds, knuckle and bottom of Tank 24l-AW- } \\
103\end{array}$ & 4 Weeks \\
\hline Prepare and issue tank examination report & 3 Weeks \\
\hline Prepare and issue Final Overall Tank Examination report (PA) & 3 Weeks \\
\hline
\end{tabular}


HNF-2820

APPENDIX C

REV. 1

APPENDIX C

\section{STATEMENT OF WORK \\ FOR \\ DOUBLE-SHELL TANK ULTRASONIC EXAMINATION}


HNF-2820

\section{Statement of Work for Double-Shell Tank Ultrasonic Examination}

\section{SCOPE}

The objective of this Statement of Work is to ultrasonically examine the wall, lower knuckle, and bottom of the double-shell waste storage tanks (DST's) in the Hanford Site 200 Area using ultrasonic measurement equipment operated and provided by a Seller. An initial performance demonstration of wall thinning, pit, and stress-corrosion crack flaw measurement in test specimens will be followed by the examination of a DST to detect and size wall thinning, pits, and cracks without pre-inspection or tank wall preparation.

There are 28 underground double-shell 1,000,000-gallon waste tanks located in the 200 Areas that are used to store radioactive liquid waste. The first tank was placed in service in the 1970's and the last tank was placed in service in the 1980's. Vertical, cylindrical pipe risers allow access to the annular space between the inner and outer tanks as shown in the elevation view of a typical tank (Figure 1).

\section{APPLICABLE DOCUMENTS}

2.1 SNT-TC-1A-92 issued by the American Society of Nondestructive Testing.

2.2 ASME Boiler and Pressure Vessel Code, Section V, Article 4, 1995 Edition.

\section{REQUIREMENTS}

The Seller's work task, work description, and requirements are defined in this section.

\subsection{General Requirements}

If the Seller demonstrates the ability of their measurement system (see 3.2.3.1), then the Seller must successfully perform an ultrasonic examination of a tank wall, tank knuckle, and tank bottom.

Primary Tank Wall (see Figure 2) - The Seller will examine a vertical strip (approximately 30inch wide $\mathrm{x} 35$-feet long) of the primary wall between the upper haunch transition and the lower knuckle for pits, cracks, and wall thinning. Axial cracks on the tank inner surface shall be detected and sized. The vertical strip may be comprised of one or more strips whose total width is 30 inches.

The Seller will examine welds for cracks at the following locations (see Figure 2): 20 feet of the circumferential weld joining the cylinder to the lower knuckle, one vertical weld joining the lowest shell course plates (about 10 feet of weld), and one vertical weld joining the next to the lowest shell course plates (about 10 feet of weld). Axial and circumferential cracks on the tank inner surface shall be detected and sized. 
HNF-2820

APPENDIX C

REV. 1

\subsection{General Requirements Cont'd}

Primary Tank Knuckle - The Seller will examine the primary tank lower knuckle to detect the presence of cracks oriented in the tank circumferential direction and for pits and wall thinning. The area to be examined is 20 feet long in the circumferential direction and, in the meridional direction, is from the weld joining the transition plate with the knuckle to the furthest reach of the transducer assembly that is allowed by the tank geometric constraints. The 20-foot dimension is not required to be a continuous length. Examination segments that add up to a 20foot long area are acceptable.

Secondary Tank Knuckle and Bottom - The Seller must also successfully perform an ultrasonic examination of the secondary tank lower knuckle and bottom. A 20-foot length of the knuckle will be examined over the entire area of the knuckle for the presence of circumferential cracks. The tank bottom will be examined between the primary and secondary tank walls over an area 10 $\mathrm{ft}^{2}$ to detect and measure thickness and pits. The tank bottom examination shall be at the location between the nearest two air supply pipes that appears to have the most surface corrosion.

Primary Tank Bottom -The Seller will examine the primary tank bottom for pits, wall thinning, and cracks following any necessary performance demonstration. Crack detection is limited to cracks oriented perpendicular to the air channels. The tank bottom is accessible for examination through straight-sided channels in the foundation directly below the tank. The channels are cut or formed in the insulating concrete that supports the tank 8 inches above the secondary tank floor. The details of the channel shape and size are as shown in Figure 3. In each of sixteen channels, the tank directly above the channels will be examined the width of the channel and for a distance of 12 feet towards the tank center beginning seven inches inboard of the outside radius of the tank cylindrical section. In addition, the Seller's examination equipment shall be capable of navigating around an air supply pipe (except in AP tank farm) and inspecting the tank bottom.

Access to the tank annulus is through inspection risers. There are two large risers, 24-inch in diameter, and one or two smaller risers, 12 -inch in diameter. The risers are at 90 -degree intervals around the tank. Each is approximately 20 feet long. The risers are constructed of schedule 40 ASTM A53 pipe, with a 150-pound, raised face, slip-on flange. The surface area surrounding the access riser, which terminates a few inches above grade, is gravel, with no immediate obstructions, except other risers. The radiation dose rate at any tank location is low for the workers except for radiation shine through the riser. The annual radiation dose limit for an individual is $0.5 \mathrm{rem}$ (the unit of dose equivalent). The expected accumulated individual dose is far below this limit. 


\subsection{General Requirements Cont'd}

There are several locations in the annulus that may pose obstacles to inspections. There are groups of $1 / 2$-inch conduits that run vertically along the secondary tank wall and cross the secondary tank bottom. Also in the annulus space, there are 4-inch diameter air supply pipes that run vertically to the secondary tank bottom and then cross to the primary tank insulating pad. The position and number of air supply pipes varies by tank farm as shown in Table 1. From visual examinations in the annulus space, obstructions have been observed in the air channels under the tank. The obstructions are pieces of insulating concrete, instrumentation wires, and metal bars. The Seller shall provide a means of clearing the minor obstructions to inspections, such as the pieces of concrete. Additional channels may be examined to achieve an equivalent area of examination. A video of the annulus area and of the air vent slots, of limited clarity, is available to the prospective Sellers upon request. Tanks in farms AY, AZ, and SY, have leak detection probe assemblies at three azimuthal locations that obstruct inspections. The assemblies are all similar and for AY farm tanks are shown on drawing H-2-64369.

Upon completion of the initial tank examination, Seller may be requested to examine additional tanks as described above.

\subsection{Specific Requirements}

General tank information typical of all double-shell tanks follows:

1. Primary tank lower knuckle plate thickness ranges from seven-eighths to fifteen-sixteenths (7/8-15/16") inch.

2. Primary tank bottom thickness ranges from three-eighths to seven-eighths $\left(3 / 8-7 / 8^{\prime \prime}\right)$ inch.

3. Secondary tank plate thickness ranges from one-quarter to nine-sixteenths (1/4-9/16") inch.

4. Tank surfaces are in the "as welded" condition. The welds have not been ground.

5. Annulus air temperature varies up to one hundred thirty $\left(130^{\circ} \mathrm{F}\right)$ degrees $\mathrm{F}$.

6. Annulus beta-gamma radiation rates up to one thousand (1000) $\mathrm{R} / \mathrm{hr}$.

The condition of the tank surface to be examined varies from mill scale to the coating of rust that follows in the normal weathering of steel plate. The surface is near equally divided between mill scale, transition from mill scale to a rust coating, and rust coating areas. A few laitance streaks from pouring the concrete structure over the dome, chalk used in the welds areas during the tank hydrostatic test, and miscellaneous marks used to identify materials during construction remain on the tank surface. 
HNF-2820

APPENDIX C

REV. 1

\subsection{Specific Requirements Cont'd}

A video of the annulus area and the air vent slots, of limited clarity, is available to the prospective Sellers upon request.

Workers will likely be restricted from occupying the space immediately above the riser because of the radiation shine from the waste below. Actual restriction parameters will not be known until the shielding plug is removed and a radiation survey is completed immediately prior to the examination.

It will be necessary for the Seller to lower the ultrasonic measurement equipment through a riser to perform the examination. Personnel must operate the ultrasonic equipment from grade elevation. An annular space approximately $2 \frac{1 / 2}{2}$ feet wide is available for ultrasonic equipment operation between the outer surface of the primary tank and the inner surface of the secondary tank. There should be no obstruction to movement of the ultrasonic equipment in the annular space immediately below the access riser.

The tanks are grouped in tank farms. Each farm is a controlled access area and is enclosed by a chain link fence. The riser flange cover and radiation shielding will be removed by the Hanford facility personnel. Raw water and electrical power for data acquisition equipment are available at the tank farm. The Seller must provide compressed air, if needed.

\subsubsection{Limitations and Approval Requirements}

Vehicles or equipment having a gross weight exceeding $10,000 \mathrm{lbs}$. are subject to restriction to specific areas inside the tank farm. The degree of restrictions depends upon the configuration and utilization of the vehicles or equipment. Plans describing the activities of personnel, vehicles, and equipment inside the tank farm shall be provided by the Seller for Lockheed Martin Hanford Company (LMHC) approval prior to the examination.

All required weather and dust protection structures or facilities for the Seller's workers or equipment in the tank farm shall be provided by the Seller and must be approved by LMHC before use to ensure compliance with safety and operational policy.

Unless otherwise noted herein, the Seller shall provide all design, materials, services, equipment, labor, and documents necessary to safely perform the examination in accordance with this specification. All equipment deployed in the tank and all couplant remaining in the tank in excess of 20 gallons must be removed upon completion of the examination without damaging the tank. Each worker entering the tank farm, which is a controlled access area, is required to have radiation worker training, hazardous waste worker training (24-hour), and training unique to the facility, as applicable in section 3.2.6. All personnel and equipment are surveyed for radiation contamination upon each departure from the tank farm. Specific training details are described in Section 3.2.6. 
HNF-2820

APPENDIX C

REV. 1

\subsubsection{Qualifications}

Nondestructive examination (NDE) personnel shall be qualified and certified in accordance with the recommended guidelines of the American Society of Nondestructive Testing SNT-TC-1A-92.

Prior to the examination, the Seller must provide the following documentation to LMHC for approval: NDE qualification and certification procedures; Level I, II, and III qualifications and certifications which include objective evidence of NDE training, formal education, examinations, experience, date of hire, and current eye examination for personnel; and NDE method/examination procedures that are in accordance with the applicable codes/standards.

\subsubsection{Ultrasonic Examination}

\subsubsection{Performance Demonstration}

An ultrasonic examination of test specimens shall be performed by the Seller at the Seller's facility to demonstrate performance of their measurement system. The Seller shall provide a mockup of the tanks for this purpose. The following are specific requirements for the mockup.

\section{A. Deployment and Retrieval}

The mockup shall have an access riser of the diameter the Seller plans to use to gain access to the Hanford tanks (The minimum inside diameter of the 24-inch riser is 22.6 inches). The riser shall be 20 feet long or at least twice the length of the Seller's deployment equipment. The lower end of the vertical riser shall open to vertical tank walls. The vertical tank walls and riser shall be of material, strength, and size required to support the deployment equipment, deploy the inspection equipment, and retrieve the inspection and deployment equipment.

\section{B. Flaw Detection (demonstration plates will be provided by LMHC)}

1. At least one vertical steel plate shall be positioned for ultrasonic scanning. The plate will have no surface preparation.

2. A cut-out in the vertical plate shall be made to allow insertion of flat demonstration plates that are 14.5 inches by 21.6 inches and of different thickness' ( $3 / 8$ and $7 / 8$ inches). Appropriate brackets shall firmly hold the demonstration plates in the cut-out and the brackets shall not interfere with the inspection of the demonstration plate. The long dimension of the cut-out and demonstration plate shall be horizontal. 


\section{B. Flaw Detection (demonstration plates will be provided by LMHC) Cont'd}

3. The primary tank knuckle (see Figure 1) shall be simulated with a straight knuckle section (nominal thickness of $1 / 2$-inch, in shape of $1 / 4$ section of a steel pipe) and sufficient plate attached to the pipe section to allow the inspection tool to be demonstrated for its ability to inspect the knuckle as described in Section 3.1. The steel will have no surface preparation.

The secondary tank knuckle shall be simulated in the same manner as the primary tank knuckle.

4. The secondary and primary tank bottom inspection mockup shall include the area between the primary and secondary tank (annulus). The area shall be simulated with a straight section having the following obstacles included and which must be overcome to perform the inspections of the tank bottoms; i) one vertical four-inch pipe attached such that each of the air pipe spacings (radial) can be simulated, with the exception of the spacing for AP tank farm (see Table 1), and ii) four one-half inch conduits, adjacent to each other, attached to the secondary wall, oriented vertically, and running to the tank floor and then fanning out across the annulus space at 30 degree separation and terminating at the base of the tank foundation. The mockup annulus shall be of adequate length to properly demonstrate the inspection equipment's capability to overcome the obstacles to the inspection.

Each of the air vent geometries shall be simulated (see Figure 3) and each shall be thirteen feet long. The insulating concrete may be simulated with Portland cement and the height of the insulating concrete shall be accurately represented ( 8 inches). The plate in front of the vents in details 4 and 5 of Figure 3 shall also be included for those particular vent geometries. The primary and secondary tank knuckles shall be included in the mockup (see item 3 above). A 3/8-inch thick flat steel plate, 11 feet long, shall simulate the primary tank bottom and cover the air vents or be designed to be moved over each vent type individually. A curved section (pipe section) shall be welded to the flat plate to simulate the primary tank knuckle. The primary tank bottom and knuckle shall be positioned over the air vents as shown in Figure 3. There will be approximately two feet of "insulating" concrete and vents not covered by the primary tank bottom plate. This area shall be used to place demonstration plates for testing the inspection equipment.

A single mockup or multiple mockups may be made as long as they meet the characteristics described above (mockup requirements $\mathrm{A}$ and $\mathrm{B}$ ). 
HNF-2820

APPENDIX C

REV. 1

\section{B. Flaw Detection (demonstration plates will be provided by LMHC) Cont'd}

LMHC will provide test specimens containing crack, pit, and thinning flaws to allow demonstration of the Seller's ability to detect and size the flaws as follows (all accuracy requirements are RMS values):

Pits - Seller to size the depth dimension within 0.050 -inch accuracy.

Thinning - variable thickness. Seller to size the thickness within .020 inch accuracy.

Cracks - Seller to detect the existence of a crack at the inner wall surface on the primary tank and size the crack depth within 0.1 -inch accuracy. The crack orientation will be provided by LMHC. For the secondary knuckle, the Seller is to detect cracks at both the inner and outer surface and size the crack depth within 0.1 inch.

As part of the performance demonstration, the Seller shall examine eighteen test specimens; six for a wall examination demonstration, six for a weld examination demonstration, and six for a primary tank bottom examination demonstration. If the knuckle examination transducers are not the same as the wall examination transducers, another six plates shall be examined.

\subsubsection{Tank Examination}

Upon successful completion of the performance demonstration, the Seller shall perform the ultrasonic examination of the tank. The Seller shall provide a calibration block to verify proper function of the examination system immediately before and after the examination.

The examination goal is to determine whether the tank owner is required to take special action (see "*" below). The ultrasonic examination shall detect any pit whose depth exceeds $25 \%$ of the wall thickness and wall thinning that exceeds $10 \%$ of the wall thickness and cracks exceeding a depth of 0.18 inches. Hemisphere configuration is assumed for the pit. Differentiation between laminations and corrosion shall be provided by the Seller. The examination data shall identify the location of any anomalous indications within \pm 1 inch.

* NOTE: Pit depth that exceeds $50 \%$ of the wall thickness, thinning that exceeds $20 \%$ of the wall thickness, and surface crack depths that exceed 0.18 inches are considered significant and will cause the tank owner to take special action. 


\subsubsection{Foreign Material}

The Seller shall provide a chemical description and identify the quantities of couplant and any other substance introduced into the annulus that remains in the annulus following the examination.

\subsubsection{Visual Information}

The Seller shall provide a closed circuit television system to continuously view the ultrasonic examination process. The Seller and LMHC shall provide a monitor for viewing during the examination process. The examination image shall be recorded on videotape and provided to LMHC at the completion of the examination; it shall also contain the tank designation, the riser designation, time, and date.

\subsubsection{Ultrasonic Examination Procedure}

The ultrasonic examination shall be conducted in accordance with the requirements of the ASME Boiler and Pressure Vessel Code, Section V, Article 4, 1995 edition, and the requirements identified herein. In addition, the Seller shall provide a copy of the calibration block certification.

\subsubsection{Sequence of Seller Performance}

1. Performance demonstration in accordance with the requirements herein.

2. Ultrasonic examination of the tank wall, lower knuckle, and tank bottom as described herein.

3. Ultrasonic examination of additional tanks as described herein.

Item \#2 and \#3 will include videotape of the examination, an examination evaluation report, and a report and record of the examination in accordance with the requirements of the ASME Boiler and Pressure Vessel Code, Section V, Article 4, or the equivalent. The seller shall also provide hard copy records (B or C-scan) and the electronic records of the areas inspected. The hard copy and the electronic records shall include samples of A-scans (amplitude of front and back wall echoes) for the performance demonstration plate, calibration plate, and for each of the areas inspected.

\subsubsection{Acceptance Criteria}

Completion of the ultrasonic examination in accordance with the requirements set herein. 
HNF-2820

APPENDIX C

REV. 1

\subsubsection{Training Requirements}

The following training will be required for each person performing work in the 200 area. All worker training is available at the Hanford site at the expense of Lockheed Martin Hanford Corporation (LMHC), excluding the worker salary and sustenance.

\subsubsection{Training for Workers Inside the Tank Farm}

\subsection{Radworker 1}

Course $\# 020001,21 / 2$ days or one day test.

3.2.6.1.2. $\quad 24$ hour Hazworker Training

Course $\# 031110,2$ days or previous qualification.

3.2.6.1.3. Hazworker Physical

HEHF Lisa M. Whitemore, 376-4122

\subsection{Building Emergency Plan Review}

Course \#03E060, scheduled by appointment, approximately 2 hours.

\subsection{Tank Facility Orientation}

Course \#350710, scheduled by appointment, approximately 2 hours.

\subsubsection{Training for Workers or Visitors Outside the Tank Farm}

\subsection{Building Emergency Plan Review}

Course \#03E060, scheduled by appointment, approximately 2 hours.

\subsection{Tank Facility Orientation}

Course \#350710, scheduled by appointment, approximately 2 hours. 
HNF-2820

\section{SCHEDULE}

The Seller shall be available and prepared to begin the performance demonstration within 60 calendar days following the receipt of order. The demonstration activity and the initial tank measurement shall be completed within 30 days. Inspection of additional tanks will commence after October 1, 1998.

A tentative schedule of the events to be done in the 30 days are as follows:

1. Demonstration measurement of test specimens - five days

2. Evaluation of the demonstration measurement by $\mathrm{LMHC}$ - one day

3. Travel to Richland followed by one week of Training - eight days

4. Set up at tank farm - one day

5. Perform primary tank bottom examination - six days

6. Perform the primary tank wall, primary tank knuckle, secondary tank knuckle, and secondary tank bottom examination - eight days

7. Remove the equipment from the tank farm - one day

The demonstration measurement of the test specimen does not require special training. 
HNF-2820

APPENDIX C

REV. 1

Table 1. Tank Details

\begin{tabular}{|c|c|c|c|}
\hline $\begin{array}{l}\text { Tank } \\
\text { Farm }\end{array}$ & 4" Dia. Air Supply Pipes & $\begin{array}{l}\text { No. of Air Vent Slots at } \\
\text { Annulus }\end{array}$ & $\begin{array}{l}\text { Reference } \\
\text { Drawing }\end{array}$ \\
\hline$\overline{\mathrm{AN}}$ & $\begin{array}{l}\frac{8 @ 45}{a t} \text { deg. } \\
\text { at } 37 \text { '-11" Radius }\end{array}$ & 64 & $\mathrm{H}-2-71960$ \\
\hline AP & $\begin{array}{l}\frac{8(45)}{\text { at } 39} \text { ' deg. } \\
\text { " Radius }\end{array}$ & 64 & $\mathrm{H}-2-90440$ \\
\hline $\mathrm{AW}$ & $\begin{array}{l}\frac{8 @ 45}{a} \text { deg. } \\
\text { at } 37 '-11 " \text { Radius }\end{array}$ & 64 & $\overline{\mathrm{H}-2-70304}$ \\
\hline $\mathrm{AY}$ & $\frac{4(090}{\text { at } 38 '-4 " \text { deg. }}$ Radius & 72 & H-2-64307 \\
\hline$\overline{\mathrm{AZ}}$ & $\begin{array}{l}4 @ 90 \text { deg. } \\
\text { at } 37 '-11 " \text { Radius }\end{array}$ & 64 & $\mathrm{H}-2-67244$ \\
\hline SY & 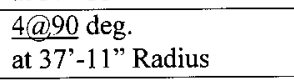 & 64 & $\mathrm{H}-2-37705$ \\
\hline
\end{tabular}


INNF-2820

APPENDIX C

REV. 1

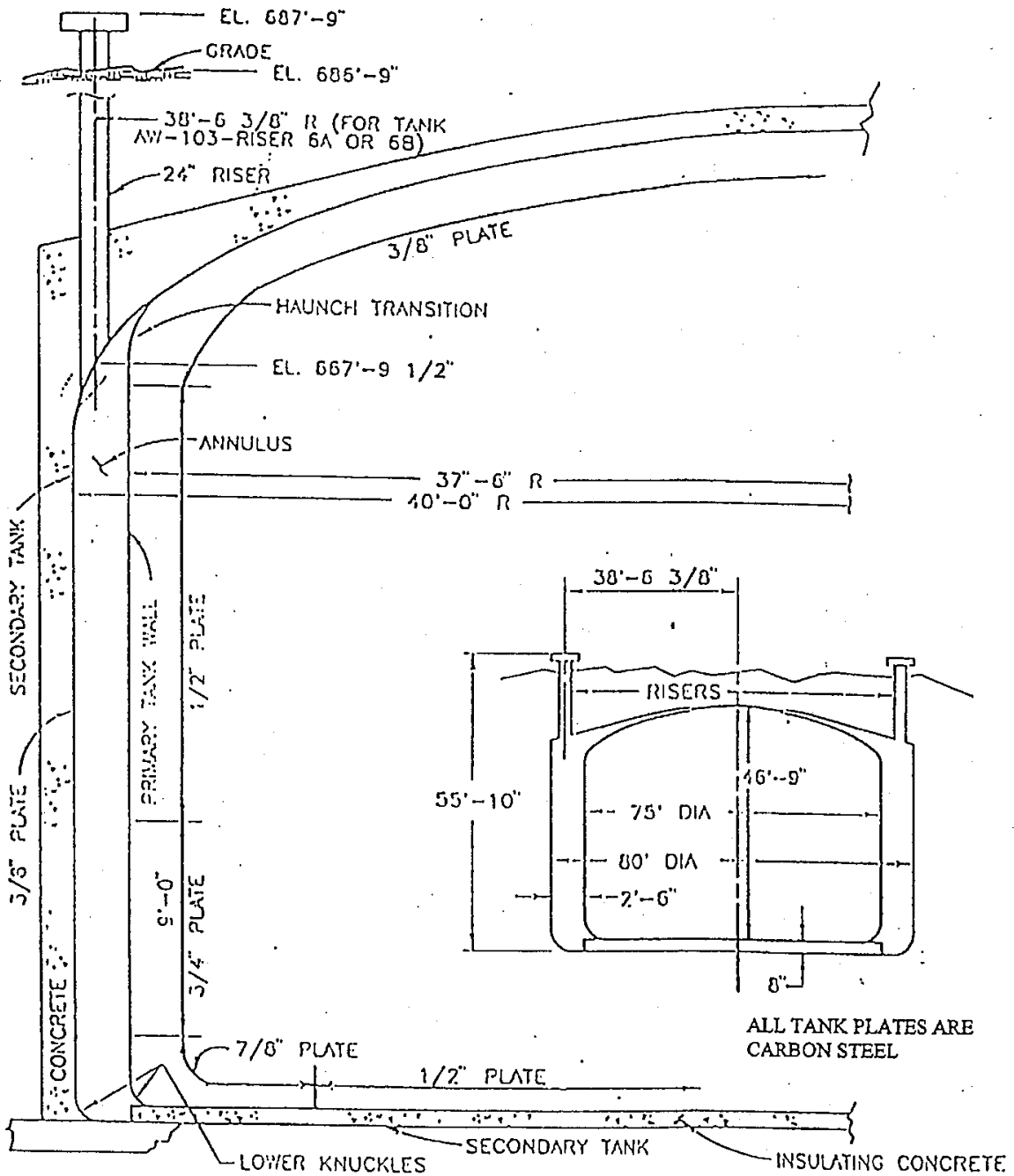

liIGUIR: 1.

TSPICAL ILLEVATION VIEN

(No SCAIII) 
HNF-2820

APPENDIX C

REV. 1

Wall Examination of Wolds and 30-Inch Wide Aren

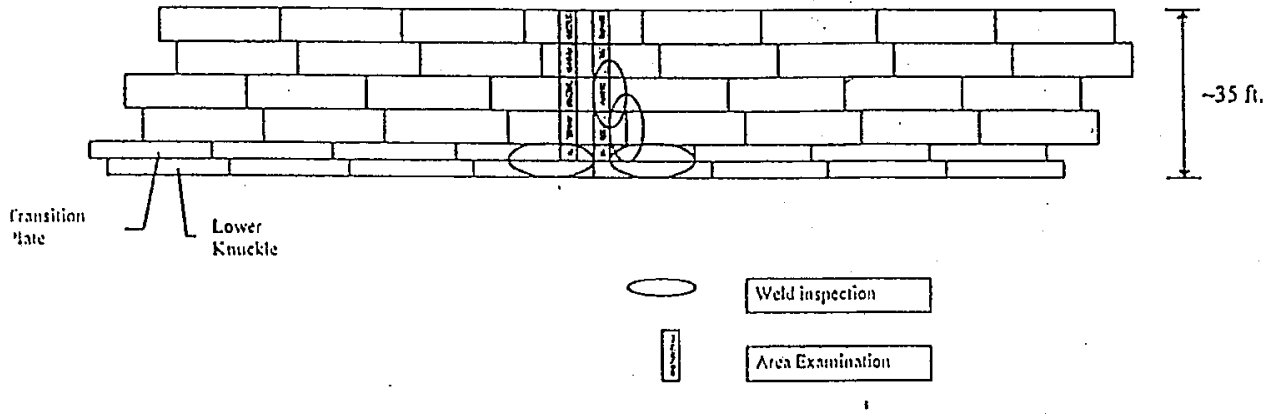

Jigure 2. Tank Layout

Tanks arc construcled of threc or four major slicll courscs, approximatcly 30 fect long and cight $10 \mathrm{ten}$ fect witc. The lower knuckle is onc foot high and there is a transition phate of nboul one foot height belween the knuckle nud the lower sliell course. 
HNF-2820

APPENDIX C

REV. 1
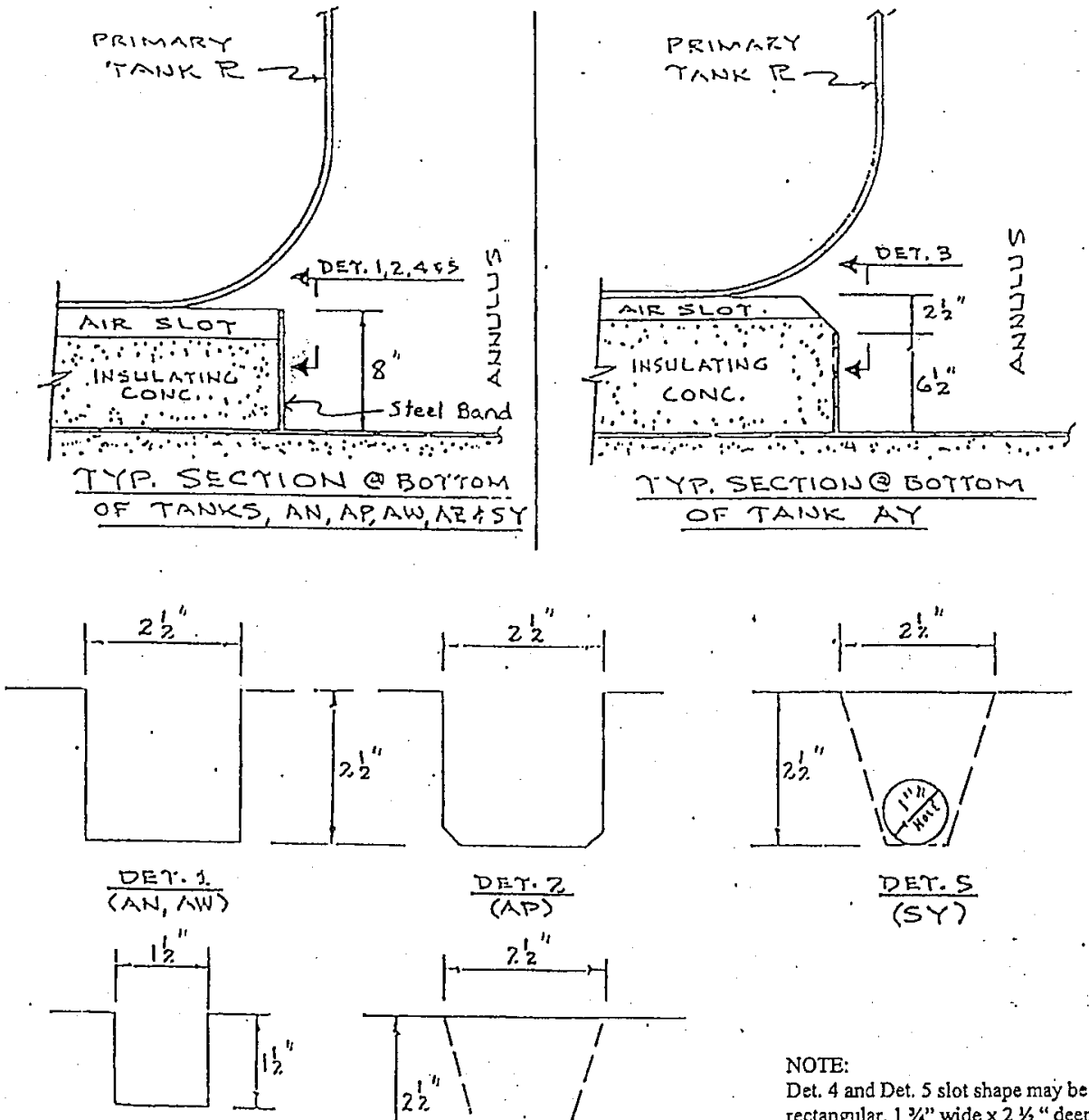

$\frac{\text { DET.S }}{(S Y)}$

NOTE:

Det. 4 and Det. 5 slot shape may be rectangular, $1 \%$ " wide $\times 21 / 2$ " deep

PIGURE 3.

$\frac{D E R \cdot 3}{(A Y Y)}$

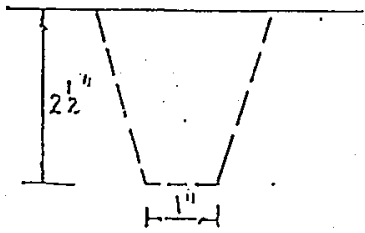

$\frac{D E T \cdot A}{(A Z)}$

JRIITURN AIR VENT SLOTS 